\title{
SUSTAINABILITY ASSESSMENT OF THE RESIDENTIAL CONSTRUCTION PROJECTS IN LITHUANIA
}

\author{
Loreta KANAPECKIENE ${ }^{1}$, Laura TUPE்NAITE ${ }^{1 *}$, \\ Greta SAULYTE் JUCIENE ${ }^{2}$, Ineta GEIPELE ${ }^{3}$ \\ ${ }^{1}$ Department of Construction Management and Real Estate, Faculty of Civil Engineering, \\ Vilnius Gediminas Technical University, Vilnius, Lithuania \\ ${ }^{2}$ State Enterprise Turto Bankas, Vilnius, Lithuania \\ ${ }^{3}$ Institute of the Civil Engineering and Real Estate Economics, Faculty of Engineering Economics \\ and Management, Riga Technical University, Riga, Latvia
}

Received 23 April 2020; accepted 10 May 2021

\begin{abstract}
Development of real estate has the potential to advance sustainability. This is particularly important in residential sector as it plays a crucial role in the lives of habitats and directly influences their welfare. As populations grow and cities expand, the demand for real estate increases and construction volumes rise. Assurance of sustainability in the residential projects becomes a new concern of real estate developers and construction companies.

This article aims to analyse in more detail the concept of a sustainable residential construction and the evaluation criteria. In the first part the concept of sustainable development and its dimensions in residential construction are analysed. The second part describes the research methodology. In the third part, the research methodology is applied to the evaluation of five residential construction projects in Vilnius, Lithuania. The fourth part describes the possibilities of using wooden construction to improve the sustainability of residential construction projects.
\end{abstract}

Keywords: sustainability, residential construction, multi-criteria assessment, COPRAS method, SAW method, wooden buildings.

\section{Introduction}

The development of society is inextricably linked to the increasing negative impact on the environment. In recent centuries, high economic and human population growth has led to irrational use of resources, environmental pollution and unproductive lifestyles. In the middle of the 20th century, the scientific-technical revolution led to a multifold increase in production, use and consumption of natural resources. For these reasons, today's society places great emphasis on sustainable development, seeking to reconcile economic, social and environmental needs.

With the spread of sustainable development ideas, the development of new sustainable residential projects has recently gained increasing attention. Sustainability is expressed in terms of reconciling economic, social and environmental needs, which makes it difficult to define what constitutes a sustainable residential construction project. In order to assess whether a project is sustainable, it is not possible to select a single area or criterion that can be used as a guide and a priority indicator for evaluation; therefore, multi-criteria evaluation methods are used to carry out integrated evaluation of the projects to select the most efficient alternatives.

Lithuania follows sustainable development goals (SDGs) set in the United Nations Agenda 2030. Country devotes much attention to the sustainable development of cities and communities. The new general plan of the territory of Lithuania that is currently being developed will integrate the SDGs. It will become the key instrument for ensuring inclusive and sustainable urban development, reducing the socio-economic exclusion of cities and the negative impact of built-up territories on the environment, and securing the protection of natural and cultural heritage (United Nations, 2018).

This article aims to analyse in more detail the concept of a sustainable residential construction project and the evaluation criteria. A proposed methodology for the mul-

*Corresponding author. E-mail: laura.tupenaite@vilniustech.lt 
ti-criteria assessment of the sustainability of new residential construction projects is presented. The methodology is practically applied to the evaluation of five residential construction projects in Vilnius, Lithuania. In addition, the article provides an overview of the possibilities of applying wooden construction in the future perspective.

\section{Sustainable residential construction}

Sustainability is defined in the scientific literature as the relationship between society and the environment, taking into account economic, social and environmental factors. These three components form the basic idea of sustainability: the needs of the present generation should be met without compromising the ability of future generations to meet their own needs (World Commission on Environment and Development, 1987). This is currently one of the most important objectives, not only in terms of political, economic or ecological direction, but also of great importance in the field of real estate development.

The main principles of sustainable development were formulated at the World Summit in Rio de Janeiro in 1992. Sustainable development was established as the main ideology for the long-term development of society. The concept of sustainable development rests on three equally important dimensions, namely economic sustainability, social sustainability, and environmental sustainability. However, recently it has been noted that the three dimensions do not include the very important political dimension. Indeed, sustainability transitions have political nature. Discussions on climate policy are influenced by national and international politics. Furthermore, sustainability transitions involve network governance in which private, public, and societal actors are involved (Ottens \& Edelenbos, 2019).

When assessing the sustainability of residential construction projects and setting criteria, it is important to take into account the four dimensions of sustainability mentioned above. From this point of view, "building sustainability involves "green building" design and construction, taking account of both environmental elements and economic benefits, along with social obligations to the society we live in" (Janjua et al., 2019).

The economic sustainability of housing includes the following indicators: the price of housing, low inflation rates, favourable conditions for home ownership, i.e. low interest rates (Ginsberg, 2016). The affordability condition is also relevant to economic sustainability (Golubchikov \& Badyina, 2012). According to Mulliner et al. (2013), "sustainable communities must provide decent homes at prices people can afford". Based on Ahmad and Thaheem (2018), three main parameters that can be used to assess sustainability are affordability, adaptability and flexibility, and manageability.

Social sustainability is an important part of sustainable housing (Ahmad \& Thaheem, 2017). Sustainable housing has to be available, good quality, economical, ecological, comfortable and cosy (Zavadskas et al., 2017). Housing planning must be seen as a complex issue, closely linked to the provision of essential services and transport infrastructures, the network of social services, integrity and accessibility. For communities to be sustainable, residential areas must provide hospitals, schools, shops, good public transport, open public spaces and a clean and safe environment (Zavadskas et al., 2017). According to Tupenaite et al. (2017), housing not only provides a place to live, but also a sense of security for the future and a strong sense of local community.

Environmental sustainability is mostly researched in the literature and extensively used in certification systems, such as Building Research Establishment Environmental Assessment Method (BREEAM) and Leadership in Energy and Environmental Design (LEED). In addition, the focus is being extended from the finished building to the building process (Schmidt, \& Osebold, 2017). Extensive number of indicators have been proposed for environmental sustainability assessment of the residential buildings, e.g., efficient use of land, ecosystem preservation, water efficiency, energy savings, reduction of $\mathrm{CO}_{2}$, indoor environmental quality, reduction of external pollution, use of renewable and sustainable materials, waste management (Tupenaite et al., 2017). Environmental sustainability criteria can be divided into following categories: global warming potential, emissions to the air, water and soil, water efficiency, and resources depletion (Bragança et al., 2010).

Political sustainability is also very important in achieving sustainable development goals in terms of cooperation between citizens, civil society, scientific institutions, the private sector and different levels of government. According to Sullivan and Ward (2012), sustainable housing agendas must adopt a holistic approach, which embraces community and social organizational development, as well as fiscal and juridical policy dimensions.

In summary, sustainable residential construction projects must provide a better quality of life for people. Urban location, infrastructure, accessibility to education and medical facilities, population density and environmental pollution are all important indicators of housing quality. Therefore, current developers of residential construction projects must not only build residential buildings and meet financial targets, but also take responsibility for the environment and society. It can be argued that the concept of sustainable residential construction projects is difficult to define because it consists of many economic, social, environmental and political criteria that encompass it.

\section{Methodology}

With the rapid pace of real estate development, a fundamental question arises as to how to reconcile the economic, social, environmental and political dimensions in the latest residential construction projects. As sustainability needs to be assessed in relation to the four main dimensions (see Section 1), it is not possible to choose one area 
or criterion. Therefore, Multiple Criteria Decision Making (MCDM) methods can be used, which help to quantify any complex phenomenon and to select the best alternative according to a number of criteria (Nuuter et al., 2015; Zavadskas et al., 2017; Tupenaite et al., 2018).

The basic steps of the multi-criteria sustainability assessment are presented in Figure 1.

Steps 1-2: According to the flowchart in the Figure 1 , the first step is to carry out a market analysis and the second step is to identify the alternatives (projects) under consideration.

Step 3: Determination of criteria and their significances.

In this step the most important criteria for sustainability assessment of the projects are selected. It is recommended to perform literature review for this purpose and to distinguish the most relevant criteria for particular (country or city) context. Criteria have to address all dimensions of sustainability: economic, social, environmental and political.

Next, the significances of criteria are determined based on expert opinions according to Eqs (1) and (2) (Zavadskas \& Kaklauskas, 1996):

$$
\begin{aligned}
\bar{t}_{i} & =\frac{\sum_{k=1}^{r} t_{i k}}{r} ; \\
q_{i} & =\frac{\bar{t}_{i}}{\sum_{i=1}^{m} \sum_{k=1}^{r} t_{i k}},
\end{aligned}
$$

where $t_{i k}$ is the ranking (score) of the $i$-th criterion by the $k$-th expert; $r$ - number of experts; $\overline{t_{i}}$ - the average value of the criterion ranking; $\sum_{i=1}^{n} \sum_{k=1}^{r} t_{i k}-$ the sum of the average rankings of the criteria; $m$ - the number of assessment criteria.

The consistency of the evaluation can be measured by the Kendall's (1970) coefficient of concordance of the expert opinions $(W)$, which indicates the degree of overlap between individual opinions. The concordance coefficient is equal to $1-$ if all the experts' rankings are the same, 0 - if all the rankings are completely different.

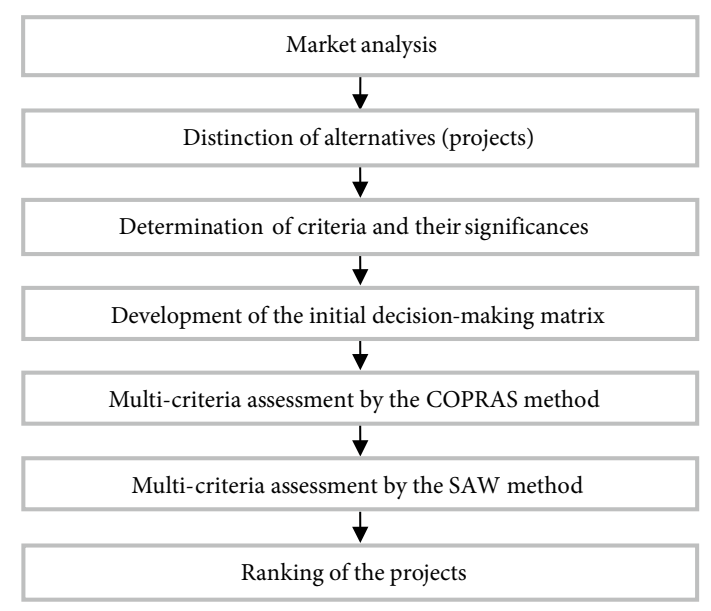

Figure 1. Flowchart of the assessment methodology
Step 4: Development of the initial decision-making matrix. Decision-making matrix consists of alternatives and assessment criteria and can be expressed as follows:

$$
P=\left[x_{i j}\right]_{[m \times n]}, i=\overline{1, m} ; j=\overline{1, n},
$$

where $n$ is the number of assessed construction projects; $m$ - the number of assessment criteria; $x_{i j}$ - the attribute value of the $j$-th construction project.

Step 5: Multi-criteria assessment by the Complex Proportional Assessment (COPRAS) method. The COPRAS method was introduced by Zavadskas and Kaklauskas (1996). Calculations are carried out in the following steps:

1. An estimated normalised decision-making matrix is developed:

$$
d_{i j}=\frac{x_{i j} q_{i}}{\sum_{j=1}^{n} x_{i j}}, i=\overline{1, m} ; j=\overline{1, n} .
$$

2. For each project alternative, the sums that take into account all $d_{i j}$ values for minimizing criteria $\left(S_{-j}\right)$ and all $d_{i j}$ values for maximizing criteria $\left(S_{+j}\right)$ are calculated:

$$
S_{+j}=\sum_{i=1}^{m} d_{+i j} ; S_{-j}=\sum_{i=1}^{m} d_{-i j}, i=\overline{1, m} ; j=\overline{1, n} .
$$

3. The relative efficiency of the compared alternatives $\left(Q_{j}\right)$ is determined on the basis of the positive $S_{+j}$ and the negative $S_{-j}$ values according to the Eq. (6):

$$
Q_{j}=\frac{S_{-\min } \sum_{j=1}^{n} S_{-j}}{S_{-j} \sum_{j=1}^{n} \frac{S_{-\min }}{S_{-j}}}, j=\overline{1, n},
$$

where $S_{-\min }$ is the minimum value among the $S_{-j}$ values calculated for each alternative.

The greater is the $Q_{j}$, the higher is the efficiency of the project alternative.

Step 6: Multi-criteria assessment by the Simple Additive Weighting (SAW) method. One of the simplest and most widely used methods is the SAW method (MacCrimmon, 1968); therefore, it was selected by the authors to validate research results, obtained by using the COPRAS method.

The SAW approach uses the following steps:

1. The decision-making matrix (Eq. (3)) is normalised:

$$
d_{i j}=\frac{\min _{i} x_{i j}}{x_{i j}},
$$

if preferable is minimum of the $i$-th attribute;

$$
d_{i j}=\frac{x_{i j}}{\max _{i} x_{i j}},
$$

if preferable is maximum of the $i$-th attribute.

2. The efficiency of the alternative (project) is determined. The members of the normalised matrix are multiplied by the significances of criteria and summed:

$$
Q_{j}=\sum_{j=1}^{n} q_{i} d_{i j} \text {. }
$$


The greater is the $Q_{j}$, the higher is the efficiency of the project alternative.

Step 7: Ranking of the projects. After the calculations have been carried out, the evaluation results obtained are compared and the project alternatives are ranked according to their efficiency indexes. Thus, the most efficient projects in terms of sustainability are selected.

\section{Case study: multi-criteria sustainability assessment of the residential construction projects in Vilnius}

\subsection{Description of the selected projects}

Five implemented residential construction projects were selected to assess their sustainability. The selection was based on the location of the projects in the city, with projects located in residential districts, suburban areas, industrial areas and the city centre. A description of the projects is given in Table 1.

\subsection{Evaluation criteria and determination of their significance}

Following the analysis of the scientific literature, $10 \mathrm{cri}-$ teria have been selected to assess the sustainability of the residential construction projects, which are presented in Table 2.

A survey of experts was conducted to identify the most important criteria for assessing the sustainability of the projects. The survey was carried out among 10 experts from the construction/real estate sector: 3 real estate appraisers, 4 real estate developers and 3 representatives of construction companies. The experts were asked to rank the criteria from 1 to 10 by order of importance. The significances of the criteria were determined on the basis of
Eqs (1) and (2). To determine the consistency of experts' opinions, the concordance coefficient was calculated: $W=$ 0.547 .

The expert assessment of the significances of the criteria showed that the most important criteria for assessing the sustainability of the projects are the accessibility of urban infrastructure $\left(q_{5}=0.117\right)$, the energy performance class of the building $\left(q_{1}=0.109\right)$, and the average price of the apartments $\left(q_{5}=0.107\right)$.

\subsection{Multi-criteria assessment of the residential projects}

The initial decision-making matrix is presented in Table 3.

For the COPRAS method, the calculations were carried out according to Eqs (4) to (6), and for SAW method - according to Eqs (7) and (8). Results are presented in Tables 4 and 5.

The calculated efficiency indexes $Q_{j}$ of the comparative alternatives expresses the sustainability of the residential construction projects. The resulting order of priorities by the both COPRAS and SAW methods is as follows: $A_{1} \succ A_{3} \succ A_{2} \succ A_{5} \succ A_{4}$.

The multi-criteria assessment of the projects showed that the most sustainable project is Karaliaučiaus slenis $\left(A_{1}\right)$. It is the best rated project in terms of price, infrastructure and energy performance. The second-best project is Bajoru alejos $\left(A_{3}\right)$. Although the infrastructure is only satisfactory, the project has the lowest average apartment price, A energy efficiency class and the best environmental performance.

The lowest scored project is CNTRL $\left(A_{4}\right)$. Although the infrastructure is well developed, the project has a high average apartment price, making it the least affordable for residents.

Table 1. Description of the projects

\begin{tabular}{|c|c|}
\hline \multicolumn{2}{|c|}{ Karaliaučiaus slènis, Elbingo st. 61, Pilaitė $\left(A_{1}\right)$} \\
\hline$\frac{d=6}{6}+6$ & $\begin{array}{l}\text { The project is developed in the Pilaite district. Pilaite is one of the newer districts } \\
\text { in Vilnius. The project was implemented in a new area, extending the boundaries } \\
\text { of the district and creating new infrastructure. The project includes } 5 \text { four-storey } \\
\text { apartment buildings and } 18 \text { townhouses. The energy class of the buildings is A+. } \\
\text { The project was focused mainly on young families, so it includes leisure areas, } \\
\text { children's playgrounds, outdoor exercise machines, sunbeds for recreation, bicycle } \\
\text { paths (Karaliaučiaus slenis, 2021). } \\
\text { Shops, schools and other public services are within } 1 \mathrm{~km} \text {, and the city centre is } 9 \\
\mathrm{~km} \text { away. }\end{array}$ \\
\hline \multicolumn{2}{|c|}{ LightHouse, Fabijoniškių st. 5, Fabijonšikès $\left(A_{2}\right)$} \\
\hline 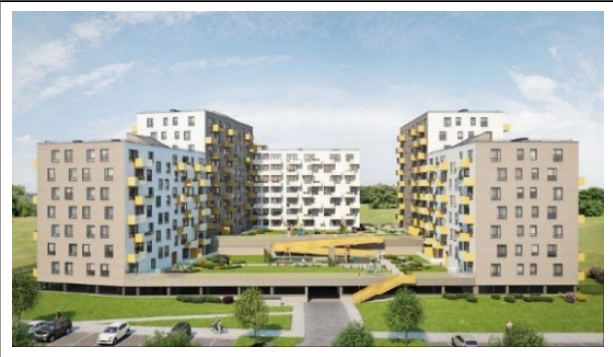 & $\begin{array}{l}\text { The project was developed in the Fabijoniškès district. The area is dominated by } \\
\text { old-built apartment buildings, with newer apartment buildings in the western } \\
\text { part of the district. LightHouse is a project with a complex of six apartment } \\
\text { buildings. The project was built in a densely built-up area. The surrounding } \\
\text { area consists of five- and nine-storey reinforced concrete apartment blocks. The } \\
\text { complex is close to children's playgrounds, green areas and the Cedron Upper } \\
\text { Landscape Reserve. Two blocks of flats have terraces on the roofs. The buildings } \\
\text { have an energy class B (Darnu Group, 2021). } \\
\text { Kindergartens, schools and other public services can be reached within } 1.5 \mathrm{~km} \text {, } \\
\text { while the city centre is } 6 \mathrm{~km} \text { away. }\end{array}$ \\
\hline
\end{tabular}


End of Table 1

\begin{tabular}{|c|c|}
\hline \multicolumn{2}{|r|}{ Bajorų alëjos, Salaspilio st. 2, Bajorai $\left(A_{3}\right)$} \\
\hline 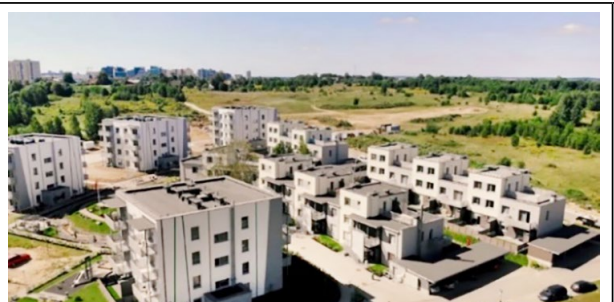 & $\begin{array}{l}\text { Bajorai is a suburban district of Vilnius, predominantly made up of individual } \\
\text { houses. The development consists of a block of } 7 \text { houses, comprising } 4 \text { four-storey } \\
\text { houses and } 3 \text { townhouses. } \\
\text { The project has a strong focus on the environment, as there are many green areas } \\
\text { around. The area has enclosed courtyards with green areas. The energy class of } \\
\text { the buildings is A (Bajoru alejos, 2021). } \\
\text { The complex is } 3 \mathrm{~km} \text { from supermarkets, schools and other public services, } 11 \\
\mathrm{~km} \text { from the city centre. }\end{array}$ \\
\hline \multicolumn{2}{|r|}{ CNTRL, Labdarių st. 6A, Senamiestis $\left(A_{4}\right)$} \\
\hline & $\begin{array}{l}\text { The project was developed among old residential, office and service buildings, } \\
\text { and is located in Labdariai Street. } \\
\text { It is a four-storey apartment building with a penthouse. The distances between } \\
\text { the buildings are small. The project is located away from the main streets of the } \\
\text { Old Town, where traffic is restricted and noise is less audible. The project consists } \\
\text { of } 37 \text { apartments, so the community is small. The project has underground } \\
\text { parking with an electric car charging station and bicycle storage. The building is } \\
\text { energy class A (Citify, 2021). } \\
\text { Supermarkets, schools and other public services can be reached within } 500 \mathrm{~m} \text {. }\end{array}$ \\
\hline \multicolumn{2}{|r|}{ Paplaujos 1, Paplaujos st. 9, Užupis $\left(A_{5}\right)$} \\
\hline & $\begin{array}{l}\text { The project is being developed in the area of the new Užupis. This is a former } \\
\text { industrial area. Several decades ago, the area was used for industrial activities, } \\
\text { which is why the old factory and warehouse buildings are still there. The project } \\
\text { consists of } 3 \text { five-storey apartment buildings. The buildings are energy class } \\
\text { A. There are green areas around the houses. Central heating with individual } \\
\text { metering. The area is surrounded by the Belmont Forest and Pavilnis Regional } \\
\text { Park (Paplaujos 1, 2021). } \\
\text { Supermarkets, schools and other public services can be reached within } 1.5 \mathrm{~km} \text {. }\end{array}$ \\
\hline
\end{tabular}

Table 2. Sustainability assessment criteria

\begin{tabular}{|c|c|c|c|c|}
\hline No. & Character & Criterion & Measurement units & Significance \\
\hline 1 & $q_{1}$ & Energy performance & Score from 1 to 2 according to energy class $(1-$ class $B, 2-$ class $A+)$ & 0.109 \\
\hline 2 & $q_{2}$ & $\begin{array}{l}\text { Installation of renewable } \\
\text { energy sources (RES) }\end{array}$ & Score from 1 to 2 (1 - RES not installed, 2 - RES installed) & 0.095 \\
\hline 3 & $q_{3}$ & Pollution & $\mathrm{ug} / \mathrm{m}^{3}$ & 0.102 \\
\hline 4 & $q_{4}$ & $\begin{array}{l}\text { Preservation of ecological } \\
\text { value }\end{array}$ & $\begin{array}{l}\text { Score from } 1 \text { to } 5 \text { ( } 1 \text { - lowest level of preservation of natural } \\
\text { territories, } 5 \text { - highest level of preservation of natural territories) }\end{array}$ & 0.106 \\
\hline 5 & $q_{5}$ & $\begin{array}{l}\text { Accessibility to urban } \\
\text { infrastructure }\end{array}$ & $\begin{array}{l}\text { Score from } 1 \text { to } 5 \text { ( } 1 \text { - infrastructure is poorly developed, } \\
\text { supermarkets, schools and other public services are far from the } \\
\text { buildings, } 5 \text { - the project is very well incorporated into existing } \\
\text { infrastructure) }\end{array}$ & 0.117 \\
\hline 6 & $q_{6}$ & Community development & $\begin{array}{l}\text { Score from } 1 \text { to } 5 \text { ( } 1 \text { - development of community poorly covered } \\
\text { in the project, } 5 \text { - the project extensively addresses development of } \\
\text { community, specific areas envisaged) }\end{array}$ & 0.094 \\
\hline 7 & $q_{7}$ & Population density & Number $/ \mathrm{m}^{2}$ & 0.101 \\
\hline 8 & $q_{8}$ & Average price of apartments & EUR (per average apartment) & 0.107 \\
\hline 9 & $q_{9}$ & Housing affordability & Index & 0.098 \\
\hline 10 & $q_{10}$ & $\begin{array}{l}\text { Compliance with } \\
\text { sustainable development } \\
\text { policies }\end{array}$ & $\begin{array}{l}\text { Score from } 1 \text { to } 5 \text { ( } 1 \text { - the project does not address sustainable } \\
\text { development goals, } 5 \text { - the project extensively addresses sustainable } \\
\text { development goals) }\end{array}$ & 0.071 \\
\hline
\end{tabular}


Table 3. Decision-making matrix

\begin{tabular}{|l|c|c|c|c|c|c|c|}
\hline \multirow{2}{*}{ Criteria } & \multirow{2}{*}{ Significances } & \multirow{2}{*}{ Max/Min* } & \multicolumn{5}{c|}{ Values of criteria } \\
\cline { 4 - 8 } & & & $A_{1}$ & $A_{2}$ & $A_{3}$ & $A_{4}$ & $A_{5}$ \\
\hline Energy performance & 0.109 & Max & 2 & 1 & 1.5 & 1.5 & 1.5 \\
\hline Installation of renewable energy sources & 0.095 & Max & 2 & 1 & 2 & 1 & 1 \\
\hline Pollution & 0.102 & Min & 25 & 26 & 25 & 26 & 26 \\
\hline Preservation of ecological value & 0.106 & Max & 5 & 3 & 4 & 1 & 2 \\
\hline Accessibility to urban infrastructure & 0.117 & Max & 3 & 4 & 1 & 5 & 2 \\
\hline Community development & 0.094 & Max & 2 & 2 & 2 & 1 & 1 \\
\hline Population density & 0.101 & Min & 0.001 & 0.007 & 0.001 & 0.006 & 0.001 \\
\hline Average price of apartments & 0.107 & Min & 75600 & 80100 & 70000 & 119000 & 110700 \\
\hline Housing affordability & 0.098 & Min & 100.57 & 106.56 & 93.12 & 158.31 & 147.27 \\
\hline Compliance with sustainable development policies & 0.071 & Max & 5 & 4 & 3 & 2 & 1 \\
\hline
\end{tabular}

Note: ${ }^{\star} \mathrm{Min}$ - the lower values are preferred; Max - the higher values are preferred.

Table 4. Multiple criteria assessment results (COPRAS method)

\begin{tabular}{|l|c|c|c|c|c|}
\hline \multirow{2}{*}{\multicolumn{1}{|c|}{ Criteria }} & \multicolumn{5}{c|}{ Calculation results } \\
\cline { 2 - 6 } & $A_{1}$ & $A_{2}$ & $A_{3}$ & $A_{4}$ & $A_{5}$ \\
\hline Energy performance & 0.029 & 0.015 & 0.022 & 0.022 & 0.022 \\
\hline Installation of renewable energy sources & 0.027 & 0.014 & 0.027 & 0.014 & 0.014 \\
\hline Pollution & 0.020 & 0.021 & 0.020 & 0.021 & 0.021 \\
\hline Preservation of ecological value & 0.035 & 0.021 & 0.028 & 0.007 & 0.014 \\
\hline Accessibility to urban infrastructure & 0.023 & 0.031 & 0.008 & 0.039 & 0.016 \\
\hline Community development & 0.024 & 0.024 & 0.024 & 0.012 & 0.012 \\
\hline Population density & 0.006 & 0.044 & 0.006 & 0.038 & 0.006 \\
\hline Average price of apartments & 0.018 & 0.019 & 0.016 & 0.028 & 0.026 \\
\hline Housing affordability & 0.016 & 0.017 & 0.015 & 0.026 & 0.024 \\
\hline Compliance with sustainable development policies & 0.024 & 0.019 & 0.014 & 0.009 & 0.005 \\
\hline Sums of $S_{-j}$ values & 0.060 & 0.101 & 0.058 & 0.112 & 0.077 \\
\hline Sums of $S_{+j}$ values & 0.162 & 0.123 & 0.123 & 0.103 & 0.082 \\
\hline Efficiency of the project $\left(Q_{j}\right)$ & 0.265 & 0.184 & 0.230 & 0.158 & 0.162 \\
\hline Rank & 1 & 3 & 2 & 5 & 4 \\
\hline
\end{tabular}

Table 5. Multiple criteria assessment results (SAW method)

\begin{tabular}{|l|c|c|c|c|c|}
\hline \multirow{2}{*}{ Criteria } & \multicolumn{5}{c|}{ Calculation results } \\
\cline { 2 - 6 } & $A_{1}$ & $A_{2}$ & $A_{3}$ & $A_{4}$ & $A_{5}$ \\
\hline Energy performance & 0.109 & 0.055 & 0.082 & 0.082 & 0.082 \\
\hline Installation of renewable energy sources & 0.095 & 0.048 & 0.095 & 0.048 & 0.048 \\
\hline Pollution & 0.102 & 0.098 & 0.102 & 0.098 & 0.098 \\
\hline Preservation of ecological value & 0.106 & 0.064 & 0.085 & 0.021 & 0.042 \\
\hline Accessibility to urban infrastructure & 0.070 & 0.094 & 0.023 & 0.117 & 0.047 \\
\hline Community development & 0.094 & 0.094 & 0.094 & 0.047 & 0.047 \\
\hline Population density & 0.101 & 0.014 & 0.101 & 0.017 & 0.101 \\
\hline Average price of apartments & 0.099 & 0.094 & 0.107 & 0.063 & 0.068 \\
\hline Housing affordability & 0.091 & 0.086 & 0.098 & 0.058 & 0.062 \\
\hline Compliance with sustainable development policies & 0.071 & 0.057 & 0.043 & 0.028 & 0.014 \\
\hline Efficiency of the project $\left(Q_{j}\right)$ & 0.938 & 0.702 & 0.830 & 0.578 & 0.608 \\
\hline Rank & 1 & 3 & 2 & 5 & 4 \\
\hline
\end{tabular}




\section{Building with wood for sustainability in residential buildings}

Due to global climate change, wood construction is increasingly being chosen to preserve nature and create a sustainable environment. Wood is a renewable building material, the production process of wooden structures and elements produces fewer greenhouse gas emissions compared to reinforced concrete and steel, and no carbon dioxide $\left(\mathrm{CO}_{2}\right)$ is emitted during the lifetime of a wooden building. Wood also has good thermal conductivity properties, which can be useful for saving energy during the building's use phase.

Current technologies for the production of timber structures allow for the overlapping of the spans of increasingly larger buildings, and by combining timber structures with other structures, such as metal or reinforced concrete, it is possible to achieve a large building height. The construction of a building of wooden structures is usually prefabricated and modular, which shortens the duration of construction work on the construction site. The method of production and construction of the timber frame building is sustainable and has a low negative impact on the environment. All these features are directly linked to the concept of sustainable development, which means that timber structures are expected to become increasingly popular in the future.

Wooden construction is gaining popularity worldwide, with increasingly large residential and public building projects being developed in Scandinavian countries, the UK, Austria, Canada, the USA and other countries.

One example is the Puukuokka project (see Figure 2) an 8-storey residential building in Finland, one of the first examples of multi-storey prefabricated timber structures in the world, completed in 2015 (Frearson, 2015). The complex was planned to comprise three multi-storey buildings and offer 184 apartments to the market. The second building of the complex was completed in 2017 and the third in 2018 (OOPEAA, 2021).

Puukuokka was a pilot project to develop and test a cross-layered timber module system. The entire structure and the frame of the buildings are made of solid wood and

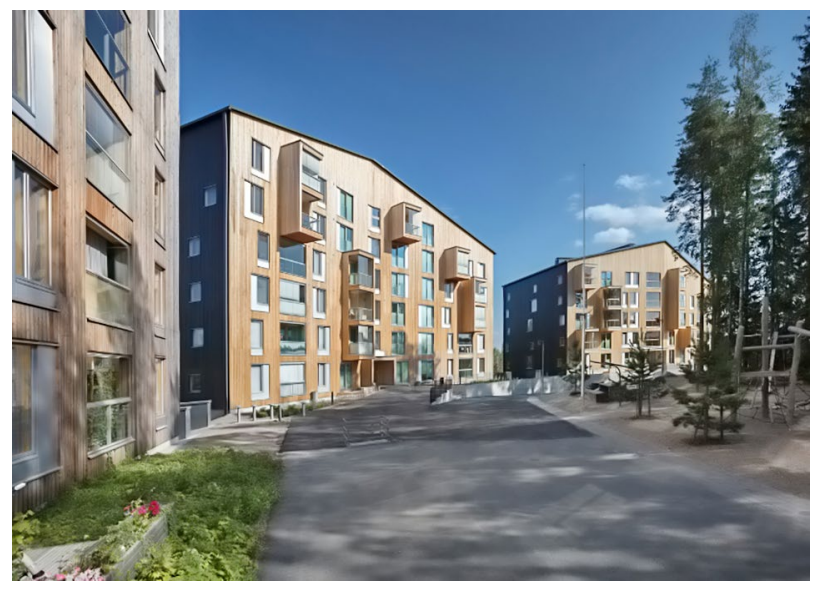

Figure 2. Puukuokka housing block (OOPEAA, 2021) consist of prefabricated volumetric modules. Each apartment has two modules: one with a living room, balcony and bedroom, the other with a bathroom, kitchen and lobby. The cross-laminated timber modules are assembled in a local factory. The use of pre-assembled modules has reduced the construction time to six months per building and reduced the impact of weather conditions (OOPEAA, 2021).

In Lithuania, the wood industry is strongly developed, but multi-storey wooden buildings are not yet constructed. Several main reasons are: lack of general knowledge about multi-storey wooden buildings, strict fire safety requirements, lack of attention to the design of multi-storey wooden buildings, lack of understanding of the benefits, and lack of training of professionals.

It can be expected that in the future, based on the good practice of foreign countries, multi-storey wooden buildings will become popular in Lithuania as well, as the ecological criterion is becoming increasingly relevant and more important for homebuyers.

\section{Conclusions}

1. Sustainable development is the link between people and their environment, taking into account the four dimensions - environmental, social, economic and political. The environmental dimension consists of ecosystems, preserving biodiversity, moderate consumption of natural resources, and reconciling production with environmental considerations. The social dimension includes improving the standard of living of the population and reducing exclusion, community cohesion and poverty reduction. The economic dimension is about ensuring continued economic growth and stable economic performance. The political dimension involves the efforts of governments and public authorities to promote sustainable development at the national level. The aim is for these four dimensions to interact with each other.

2. In order to achieve the goals of sustainable development, there is a growing need for sustainable residential construction in the context of rapid real estate development and increasing construction volumes. In order to assess the sustainability of new construction projects, multi-criteria assessment methods can be used to analyse and assess projects against a wide range of criteria, taking into account all four dimensions of sustainable development.

3. The analysis of the scientific literature has led to the development of a framework of criteria for assessing the sustainability of residential construction projects. The criteria framework consists of 10 criteria: energy efficiency, introduction of renewable energy sources, pollution, preservation of ecological value, accessibility of urban infrastructure, community development, population density, average price of apartments, affordability of housing, compliance with sustainable development policies.

4. Applying the COPRAS and SAW multi-criteria assessment methods, it was found that the most sustainable 
new residential construction project among the examined projects in Vilnius is Karaliaučiaus Slènis in Pilaite, with Bajoru Aleja in Bajorai, in the second place, and LightHouse in Fabijoniškes in the third place. It was observed that the experts attached the highest importance to the accessibility and energy efficiency of the city's infrastructure, but economic indicators, especially the average housing price, were also important in the evaluation of projects.

5. In the light of the results of the study, it is suggested that developers of new residential projects should take the following aspects into account in order to ensure that projects are sustainable: good accessibility to urban infrastructure, preservation of ecological value and creation of a community environment. In order to achieve sustainability, the construction of blocks of flats made of wood, a natural material, could be considered, based on best practice in other countries.

\section{Funding}

This work was supported by the EU Erasmus+ projects "Knowledge Alliance for Sustainable Mid-Rise and Tall Wooden Buildings" (KnoWood) (Project No: 600903-EPP1-2018-1-DK-EPPKA2-KA) and "Design and Construction of Environmental High Performance Hybrid Engineered Timber Buildings" (HybridTim) (Project No: 2020-1-DK01-KA203-075045).

\section{Author contributions}

LK and LT conceived the study and were responsible for the design and development of the data analysis. GSJ and IG were responsible for data collection and analysis. LK and LT were responsible for data interpretation. LK wrote the first draft of the article. LT and IG revised the article.

\section{Disclosure statement}

Authors do not have any competing financial, professional, or personal interests from other parties.

\section{References}

Ahmad, T., \& Thaheem, M. J. (2017). Developing a residential building-related social sustainability assessment framework and its implications for BIM. Sustainable Cities and Society, 28, 1-15. https://doi.org/10.1016/j.scs.2016.08.002

Ahmad, T., \& Thaheem, M. J. (2018). Economic sustainability assessment of residential buildings: A dedicated assessment framework and implications for BIM. Sustainable Cities and Society, 38, 476-491. https://doi.org/10.1016/j.scs.2018.01.035

Bajorų alejos. (2021). https://www.bajorualejos.lt/

Bragança, L., Mateus, R., \& Koukkari, H. (2010). Building sustainability assessment. Sustainability, 2, 2010-2023. https://doi.org/10.3390/su2072010

Citify. (2021). CNTRL project. https://citify.eu/cntrl/

Darnu Group. (2021). LightHouse. http://darnugroup.lt/en/projects/lighthouse-iii/

Frearson, A. (2015). Finland's tallest wooden apartment block wins Finlandia Prize for Architecture 2015. https://minimal- blogs.com/finlands-tallest-wooden-apartment-block-winsfinlandia-prize-for-architecture-2015/

Ginsberg, N. (2016). Determining the context of an international development project. Journal of Developing Areas, 50(5), 431442. https://doi.org/10.1353/jda.2016.0055

Golubchikov, O., \& Badyina, A. (2012). Sustainable housing for sustainable cities. UN-Habitat.

Janjua, S. Y., Sarker, P. K., \& Biswas, W. K. (2019). A review of residential buildings' sustainability performance using a life cycle assessment approach. Journal of Sustainability Research, 1, e190006. https://doi.org/10.20900/jsr20190006

Karaliaučiaus slènis. (2021). https://www.karaliauciausslenis.lt/

Kendall, M. (1970). Rank correlation methods. Griffin.

MacCrimmon, K. R. (1968). Decision making among multipleattribute alternatives: A survey and consolidated approach. RAND Memorandum, RM-4823-ARPA.

Mulliner, E., Smallbone, K., \& Maliene, V. (2013). An assessment of sustainable housing affordability using a multiple criteria decision making method. Omega, 41, 270-279.

https://doi.org/10.1016/j.omega.2012.05.002

Nuuter, T., Lill, I., \& Tupenaite, L. (2015). Comparison of housing market sustainability in European countries based on multiple criteria assessment. Land Use Policy, 42, 642-651. https://doi.org/10.1016/j.landusepol.2014.09.022

Ottens, M., \& Edelenbos, J. (2019). Political leadership as metagovernance in sustainability transitions: A case study analysis of meta-governance in the case of the Dutch National Agreement on Climate. Sustainability, 11(1), 110. https://doi.org/10.3390/su11010110

OOPEAA. (2021). Puukuokka housing block. http://oopeaa.com/ project/puukuokka-housing-block/

Paplaujos 1. (2021). http://p9.lt/apie-mus.html

Schmidt, J.-S., \& Osebold, R. (2017). Environmental management systems as a driver for sustainability: state of implementation, benefits and barriers in German construction companies. Journal of Civil Engineering and Management, 23(1), 150-162. https://doi.org/10.3846/13923730.2014.946441

Sullivan, E., \& Ward, P. M. (2012). Sustainable housing applications and policies for low-income self-build and housing rehab. Habitat International, 36(2), 312-323. https://doi.org/10.1016/j.habitatint.2011.10.009

Tupenaite, L., Lill, I., Geipele, I., \& Naimaviciene, J. (2017). Ranking of sustainability indicators for assessment of the new housing development projects: case of the Baltic states. Resources, 6(4), 55. https://doi.org/10.3390/resources6040055

Tupenaite, L., Kaklauskas, A., Lill, I., Geipele, I., Naimaviciene, J., Kanapeckiene, L., \& Kauskale, L. (2018). Sustainability assessment of the new residential projects in the Baltic States: a multiple criteria approach. Sustainability, 10(5), 1387. https://doi.org/10.3390/su10051387

United Nations. (2018). Voluntary national review on the implementation of the UN 2020 Agenda for Sustainable Development in Lithuania. https://sustainabledevelopment.un.org/ memberstates/lithuania

World Commission on Environment and Development. (1987). Our common future. http://www.un-documents.net/our-common-future.pdf

Zavadskas, E. K., \& Kaklauskas, A. (1996). Pastatu sistemotechninis ịvertinimas. Technika (in Lithuanian).

Zavadskas, E. K., Cavallaro, F., Podvezko, V., Ubarte, I., \& Kaklauskas, A. (2017). MCDM assessment of a healthy and safe built environment according to sustainable development principles: A practical neighborhood approach in Vilnius. Sustainability, 9, 702. https://doi.org/10.3390/su9050702 